\title{
DIARIUSZ \\ KALENDARIUM WAŻNIEJSZYCH WYDARZEŃ NAUKOWYCH Z udziałem pracowników Wydziału Prawa, Prawa Kanonicznego i Administracji KUL PAŹDZIERNIK - GRUDZIEŃ 2017 R.
}

\section{Październik}

3 października 2017 r. - w trakcie Convegno Internazionale: Tutele soggettive e diritti fondamentali della persona zorganizowanej w Bari (Włochy), referat wygłosili m.in. dr hab. Krzysztof Orzeszyna, prof. KUL, pt. Standard di tutela dei diritti dell'uomo nella lotta al terrorismo, dr Michał Skwarzyński, pt. Conscientious Objection in the Case Law of the ECtHR, a także dr Robert Tabaszewski, pt. Hominum causa omne ius constitutum sit. The Rule of Law and Human Rights in the Light of the European Convention of Human Rights oraz pt. New Technologies and the Paradox of Rights to Life and Health, in the Light of the Convention on Human Rights and Biomedicine.

4 października 2017 r. - w Bari (Włochy) podczas Convegno Internazionale: Tutela della persona, emigrazione e diritto alla cittadinanza, zorganizowanej przez Università degli Studi A. Moro di Bari we współpracy z l'Instituto Comprensivo „Devitofrancesco-Giovanni XXIII-Binetto” di Grumo Appula e Binetto, Grumo Appula, referaty wygłosili m.in. dr hab. Krzysztof Orzeszyna, prof. KUL, pt. Concetto di rifugiato come un soggetto particolarmente protetto dei diritti umani, dr Michał Skwarzyński, pt. Conscientious Objection, as a Human Right, with a Source of Freedom of Conscience and Religion oraz dr Robert Tabaszewski, pt. Health and Migration Process. Two Sides of the Same Coin?

12 października 2017 r. - dr Robert Tabaszewski w trakcie odbywającego się w Warszawie seminarium eksperckiego Rzecznika Praw Obywatelskich nt. Prawa pacjenta w świetle praktyki orzeczniczej sądów, wygłosił referat pt. Prawo do ochrony zdrowia w świetle art. 68 Konstytucji RP.

12-13 października 2017 r. - podczas odbywającej się w Lublinie krajowej konferencji naukowej nt. Wykładnia prawa ochrony środowiska, zorganizowanej przez Katedrę Prawa Zarządzania Środowiskiem Katolickiego Uniwersytetu Lubelskiego Jana Pawła II działającą w ramach sieci Polska sieć naukowa - Badania naukowe i prace rozwojowe na rzecz realizacji zrównoważonego rozwoju, referat wygłosiły 
m.in. dr hab. Anna Haładyj, prof. KUL, pt. Oceny oddziaływania na środowisko - między Scylla Trybunału a Charybda inwestorów, dr Kamila Sobieraj, pt. Wptyw orzecznictwa Trybunału Sprawiedliwości UE na stosowanie Konwencji z Aarhus w obszarze prawa zmian klimatu oraz prof. dr hab. Jadwiga Potrzeszcz, pt. Węzłowe problemy wykładni prawa ochrony środowiska z perspektywy teorii prawa.

12-13 października 2017 r. - podczas zorganizowanej w Warszawie Ogólnopolskiej Konferencji Naukowej nt. Wspólne wartości prawa międzynarodowego, europejskiego i krajowego, dr Michał Skwarzyński wygłosił referat pt. Wspólne wartości $w$ międzynarodowym systemie praw człowieka a problem sprzeciwu sumienia, zaś dr Robert Tabaszewski wygłosił referat pt. Zdrowie jako wartość wyższego rzędu w międzynarodowych a krajowych systemach ochrony praw człowieka. Konferencja została połączona z zebraniem sprawozdawczo-wyborczym Grupy Polskiej ILA.

17-21 października 2017 r. - w Krakowie w trakcie V Kongresu Polskich Towarzystw Naukowych w Świecie nt. Inteligencja polska w świecie, referat pt. Inteligencja polska na terenach nieokupowanych podczas II wojny (w sesji Wojenne losy uczonych) wygłosił dr hab. Sławomir Łukasiewicz.

19-20 października 2017 r. - podczas odbywającej się w Rzeszowie Ogólnopolskiej Konferencji Naukowej nt. Rzymskie korzenie procesu karnego, dr hab. Marzena Dyjakowska, prof. KUL, wygłosiła referat pt. Zasada ignorantia iuris nocet i jej znaczenie dla odpowiedzialności karnej.

20-21 października 2017 r. - w Ostrowcu Świętokrzyskim w trakcie Międzynarodowej Konferencji Naukowo-Szkoleniowej nt. Nowe Trendy w Edukacji i Praktyce Pracowników Ochrony Zdrowia, referat pt. Patient Right to Personal Security Under the Provisions of the Recommendation (2006)7 wygłosił dr Robert Tabaszewski.

23-24 października 2017 r. - dr hab. Sławomir Łukasiewicz wygłosił referat pt. Wanda Czapska-Jordan - fizyk eksperymentalny z dusza humanisty i polityka podczas konferencji naukowej: Paryż - Londyn-Monachium - Nowy Jork. Powrześniowa emigracja niepodległościowa na mapie kultury nie tylko polskiej zorganizowanej w Białymstoku.

24 października 2017 r. - odbyła się publiczna obrona rozprawy doktorskiej mgr. Pawła Niewęgłowskiego, pt. Optymalny model ochrony nabywcy na rynku nieruchomości w świetle wspótczesnego systemu ochrony konsumentów. Promotor: dr hab. Rafał Biskup, recenzenci: dr hab. Joanna Kielin-Maziarz, prof. ALK, oraz dr hab. Joanna Smarż, prof. UTH.

25-27 października 2017 r. - w Kazimierzu Dolnym podczas konferencji naukowej: Przeszłość w dyskursach publicznych. Narracje - wizualizacje - konceptualizacje 
referat pt. Wojny koncepcyjne, czyli dlaczego warto studiować historię myślenia wygłosił dr hab. Sławomir Łukasiewicz.

27 października 2017 r. - podczas Ogólnopolskiej Konferencji Naukowej nt. Dialog wielokulturowości i prawda, zorganizowanej przez Kujawsko-Pomorską Szkołę Wyższą w Bydgoszczy, referat wygłosili m.in. dr hab. Krzysztof Wiak, prof. KUL, pt. Ochrona życia i zdrowia dziecka w prawie karnym oraz dr Sławomir Hypś, pt. Ochrona dziecka przed przemoca.

27 października 2017 r. - w Opolu w trakcie Ogólnopolskiej Konferencji Naukowej: Dwie dekady Konstytucji - doświadczenia i wyzwania dr Robert Tabaszewski wygłosił referat pt. Zdrowie jako konstytucyjna przesłanka warunkujaca sprawowanie najwyższych funkcji państwowych.

\section{Listopad}

4 listopada 2017 r. - ks. dr hab. Mirosław Sitarz, prof. KUL, podczas odbywającej się w Presov (Słowacja) IV Międzynarodowej Konferencji Naukowej Filozofii i Prawa Kanonicznego nt. Współczesne wyzwania edukacji: wartości - normy - ustawodawstwo - w 425 rocznice urodzin Jana Amosa Komeńskiego, zorganizowanej przez Grecko-Katolicki Wydział Teologiczny Uniwersytetu Preszowskiego oraz Wydział Teologiczny Uniwersytetu Śląskiego w Katowicach, wygłosił referat pt. Kongregacja Edukacji Katolickiej: zadania i formy działania.

7 listopada 2017 r. - odbyła się publiczna obrona rozprawy doktorskiej mgr Anety Michałek, pt. Model kary ograniczenia wolności ukształtowany nowelizacjami Kodeksu karnego z lat 2015-2016. Promotor: dr hab. Krzysztof Wiak, prof. KUL, recenzenci: dr hab. Igor Zgoliński, profesor Kujawsko-Pomorskiej Szkoły Wyższej w Bydgoszczy oraz prof. zw. dr hab. Mirosława Melezini.

7 listopada 2017 r. - odbyła się publiczna obrona rozprawy doktorskiej mgr. Łukasza Regnera, pt. Ograniczenia jawności finansów publicznych. Promotor: dr hab. Paweł Fajgielski, prof. KUL, recenzenci: prof. zw. dr hab. Marian Zdyb oraz dr hab. Patrycja Zawadzka (UWr).

8 listopada 2017 r. - w Centrum Transferu Wiedzy KUL odbyła się Międzynarodowa Konferencja Naukowa nt. Sprawy kanonizacyjne po Sanctorum Mater - 10 lat doświadczeń zorganizowana przez Katedrę Prawa Kanonizacyjnego i Sakramentów Świętych, Instytut Prawa Kanonicznego, Wydział Prawa, Prawa Kanonicznego i Administracji oraz Katolicki Uniwersytet Lubelski Jana Pawła II, podczas konferencji referaty wygłosili m.in. prof. dr hab. Wiesław Bar (OFMConv), 
pt. Kanonizacje i beatyfikacje za pontyfikatu papieża Franciszka oraz ks. dr hab. Tadeusz Syczewski, prof. KUL, pt. Patronaty świętych i błogosławionych w Kościele łacińskim.

9-10 listopada 2017 r. - w trakcie III Ogólnopolskiej Konferencji Naukowej nt. Prawo rodzinne i spadkowe wobec współczesnych zjawisk technologicznych i społecznych, zorganizowanej w Rzeszowie przez Zakład Prawa Cywilnego Wydziału Prawa i Administracji Uniwersytetu Rzeszowskiego, referaty wygłosili m.in. dr hab. Joanna Misztal-Konecka, prof. KUL, pt. Obniżenie należnego spadkobiercy zachowku na podstawie art. 5 K.C. w praktyce sadowej (w orzecznictwie Sadu Najwyższego i sadów powszechnych), dr Paweł Wrzaszcz, pt. Rejestr spadkowy jako ochrona praw spadkobierców - ocena regulacji oraz dr Piotr Sławicki, pt. Prawo rodzinne w kontekście postępowania wieczystoksięgowego - wybrane zagadnienia.

10 listopada 2017 r. - w trakcie odbywającej się w Lublinie II Ogólnopolskiej Konferencji Naukowej nt. Rejestracja stanu cywilnego w nowej rzeczywistości informatycznej i prawnej zorganizowanej przez Ministerstwo Spraw Wewnętrznych i Administracji, Katolicki Uniwersytet Lubelski Jana Pawła II, Generalnego Inspektora Ochrony Danych Osobowych, Polską Wytwórnię Papierów Wartościowych SA, Narodowy Instytut Samorządu Terytorialnego oraz Stowarzyszenie Urzędników Stanu Cywilnego RP, referaty wygłosili m.in. dr hab. Paweł Fajgielski, prof. KUL, pt. Ochrona danych osobowych według RODO, dr Małgorzata Ganczar, pt. Udostepnianie akt stanu cywilnego po okresie przechowywania - nowe zadania kierowników USC, dr hab. Michał Domagała, pt. Kodeks postępowania administracyjnego po 1 czerwca 2017 r. oraz dr Edyta Krzysztofik, pt. Rozporzadzenie UE 2016/1191 w sprawie promowania swobodnego przepływu obywateli przez uproszczenie wymogów dotyczacych przedkładania określonych dokumentów urzędowych w Unii Europejskiej.

10-11 listopada 2017 r. - dr Katarzyna Kułak-Krzysiak w trakcie odbywającej się w Brnie (Czechy) Międzynarodowej Konferencji Naukowej nt. Days of Law 2017, sekcja Liability for Offenses (According to the Legal Regulation), zorganizowanej przez Masaryk University, wygłosiła referat pt. The Essence and Function an Administrative Penalty in the Law of Road Trafic Law.

15 listopada 2017 r. - podczas odbywającej się w Łodzi Międzynarodowej Konferencji Naukowej nt. Decentralizacja i centralizacja administracji-wspótczesny wymiar, zorganizowanej przez Katedrę Prawa Administracyjnego i Nauki Administracji Wydziału Prawa i Administracji Uniwersytetu Łódzkiego, referat pt. Granice decentralizacji wygłosiła dr Magdalena Kisała.

16-18 listopada 2017 r. - w Tallinn (Estonia) w trakcie Międzynarodowej Konferencji Naukowej: Religion, Society, State. Securitization of Religious Freedom 
- Religion and Scope of State Control, zorganizowanej przez Estonian Ministry of the Interior, University of Tartu, European Consortium for Church and State Research, Conference of European Churches - CEC i Estonian Council of Churches, ks. dr hab. Piotr Stanisz, prof. KUL, przedstawił raport pt. Securitization of Religious Freedom in Poland.

17 listopada 2017 r. - dr Judyta Dworas-Kulik w Warszawie podczas VI Ogólnopolskiej Konferencji Naukowej Młodzi Naukowcy w Polsce - Badania i Rozwój wygłosiła referaty: Problematyka prawna kredy tów frankowych w orzecznictwie TSUE oraz Ubezpieczenie Niskiego Wkładu Własnego - analiza problemu na podstawie orzecznictwa sadowego.

23-24 listopada 2017 r. - podczas X Warszawsko-Toruńskiego Kolokwium Naukowego Praw Człowieka i Międzynarodowego Prawa Humanitarnego nt. Dialog sadowy w sferze praw człowieka zorganizowanego w Warszawie, dr Robert Tabaszewski wygłosił referat pt. Litigating the Human Right to Health.

24 listopada 2017 r. - w trakcie odbywającej się we Lwowie (Ukraina) Międzynarodowej Konferencji Naukowej nt. Relacje Kościót-Państwo na Ukrainie, zorganizowanej przez Katedrę Kościelnego Prawa Publicznego i Konstytucyjnego Katolickiego Uniwersytetu Lubelskiego Jana Pawła II, Instytut Teologiczny im. Św. Józefa Bilczewskiego we Lwowie, Zakon Braci Mniejszych Konwentualnych (Ordo Fratrum Minorum Conventualium), wygłosili referat m.in. ks. dr hab. Mirosław Sitarz, prof. KUL, pt. Kształtowanie się systemów relacji Kościót-Państwo, dr Agnieszka Romanko, pt. Pluralizm systemów relacji Kościót-Państwo w epoce współczesnej oraz dr Anna Słowikowska, pt. Wkład biskupów bloku państw komunistycznych w nauczanie Soboru Watykańskiego II na temat relacji Kościót-Państwo.

24 listopada 2017 r. - dr Judyta Dworas-Kulik w Lublinie podczas VI Ogólnopolskiej Konferencji Naukowej Młodzi Naukowcy w Polsce - Badania i Rozwój, wygłosiła referaty: Polska marynarka handlowa okresu międzywojennego oraz Hipoteka morska w Polsce w okresie międzywojennym.

29 listopada 2017 r. - podczas II Ogólnopolskiej Konferencji Naukowej nt. Civis Romanus sum II. Problem interpretacji tekstu źródłowego, zorganizowanej przez Katedrę Prawa Rzymskiego, Historii Prawa i Doktryn Polityczno-Prawnych Wydziału Prawa i Administracji Uniwersytetu Szczecińskiego, referat wygłosiły m.in. dr hab. Marzena Dyjakowska, prof. KUL, pt. Źródła prawa rzymskiego jako kryterium interpretacyjne w Decisiones Lithuanicae Piotra Rojzjusza oraz dr Bożena Czech-Jezierska, pt. Problem właściwej interpretacji źródeł prawa rzymskiego w ujęciu romanistyki "marksistowskiej". 


\section{Grudzień}

1-2 grudnia 2017 r. - w Czerniowicach (Ukraina) w trakcie Międzynarodowej Konferencji Naukowej poświęconej nauczaniu klinicznemu na Ukrainie, zorganizowanej przez Czerniowiecki Uniwersytet Narodowy im. Jurija Fedkovycza, dr Aneta Biały wygłosiła referat pt. Section of Mediation and Negotiation as a New Dimension of Clinical Legal Eduaction.

7 grudnia 2017 r. - podczas odbywającej się w Lublinie Ogólnopolskiej Konferencji Naukowej - XXXV Dni Praw Człowieka nt. Pluralizm prawny i prawa człowieka. W 150-lecie urodzin Leona Petrażyckiego, zorganizowanej przez Katedrę Socjologii Prawa i Moralności Instytutu Socjologii Katolickiego Uniwersytetu Lubelskiego Jana Pawła II oraz Stowarzyszenie Naukowe Pro Scientia Iuridica, prof. dr hab. Jadwiga Potrzeszcz wygłosiła referat pt. Psychologiczna teoria prawa w działalności naukowej i społecznej Michała Orzęckiego.

7 grudnia 2017 r. - dr hab. Waldemar Bednaruk, prof. KUL, w trakcie Ogólnopolskiej Konferencji Naukowej w Lublinie zorganizowanej w ramach obchodów 700-lecia miasta Lublina nt. Lublin ośrodkiem władzy, administracji i wymiaru sprawiedliwości, wygłosił referat pt. Znaczenie Trybunału Koronnego dla rozwoju Lublina w XVIII wieku.

13 grudnia 2017 r. - ks. dr hab. dr h.c. Leszek Adamowicz w trakcie konferencji nt. Quaestiones quaedam: A due anni dall'entrata in vigore del Motu Proprio Mitis $\mathcal{E}$ Misericors Iesus w Rzymie (Włochy) wygłosił referat pt. Il nuovo processo di nullità del matrimonio. I dubbi e le difficoltà nella prassi dei tribunali in Polonia.

18 grudnia 2017 r. - w Szczytnie podczas Ogólnopolskiej Konferencji Naukowej: Bezpieczeństwo wewnętrzne państwa w obliczu fundamentalizmu religijnego, referaty wygłosili m.in. dr hab. Krzysztof Wiak, prof. KUL, pt. Gwałtowna radykalizacja postaw jako problem prawa karnego, dr Damian Szeleszczuk, pt. Sekty jako organizacje o charakterze fundamentalistycznym - perspektywa prawnokarna, dr Sławomir Hypś, pt. Granice wolności religijnej w prawie polskim oraz dr Zuzanna Gądzik, pt. Prawnokarna ocena samobójstw popetnianych z powodów religijnych.

oprac. Judyta Dworas-Kulik*

* Dr, Katolicki Uniwersytet Lubelski Jana Pawła II. 